KS. ZDZISŁAW KLIŚ

\title{
KRZYŻE IRYJSKIE
}

Krzyże celtyckie pochodzące $\mathrm{z}$ wczesnego okresu średniowiecza, sprzed w. XII zachowały się w Walii, Kornwalii, w niektórych częściach Szkocji, a nade wszystko w Irlandii. Nie można stwierdzić w jakiej relacji do siebie są poszczególne grupy krzyży. Grupa krzyży w Iona i w zachodniej Szkocji wykonana jest w tradycji iryjskiej. Klasztor w Iona był bowiem założony przez św. Kolumbę (St. Colmcille) w r. 536, po opuszczeniu Irlandii. Jako całość krzyże celtyckie sq̨ unikalne i nie znajdują odpowiedników w ówczesnej Europie.

\section{HISTORIA BADAŃ POCZATKOWYCH \\ NAD KRZYŻAMI IRY JSKIMI}

Pierwsza większa praca na temat krzyży iryjskich została napisana przez Henryego O'Neill (1798-1880). Artysta urodził się Clonmel i większość swego życia spędził w Dublinie. Jego Illustrations of the Most Interesting of the Sculptured Crosses of Ancient Ireland została wydana w r. 1857, zawierając 36 kolorowych litografii wykonanych w skali. Towarzyszącym był Essay on Ancient Irish Art and Descriptions of the Prints, bezpłatny. Po prawie stu pięćdziesięciu latach litografie O'Neilla nadal wzbudzają zachwyt i respekt. Móc studiować wygląd krzyży na podstawie tej dokumentacji jest wielkim szczęściem, ponieważ wiele $\mathrm{z}$ nich uległo zniszczeniu, w szczególności relief scen biblijnych.

Margaret Stokes (1832-1900) jako druga w kolejności zaawansowała studia nad krzyżami iryjskimi. Była najważniejszym pionierem prac nad sztuką iryjską. W w. XIX mała grupa naukowców prowadzona przez George'a Petriego, William'a Reeves'a i Lorda Dunraven pracowała nad irlandzkimi starożytnościami. Margaret Stokes wzrastała w cieniu tych ludzi, ponieważ byli przyjaciółmi jej ojca, dystyngowanego lekarza, zainteresowanego antykami. Poświęciła połowę swojego życia wyjaśnieniu rozwoju sztuki iryjskiej. Najlepiej znana jej ksiq̨żka, napisana dla wydawnictwa podręcznikowego South Kensington, jest zatytuowana Early Christian Art in Ireland (1886) i pozostała podstawowym tekstem na wiele lat. Później zapoczątkowała serię ilustracji The High Crosses of Ireland, ale tylko ich pierwsza część była skompleto- 
wana przed jej śmiercią. Pod auspicjami Royal Irish Academy w roku 1898 zostałá opublikowana część zatytuowana: High Crosses of Casiledermot and Durrow. Następnie druga część, łącznie z jej adnotacjami na temat Moone, Drumcliff, Termonfechin i Killamery, ukazała się w r. 1901, posthumus.

Henry S. Crawford opracował wspaniałą serię inwentarzy i podręcznik pt. Carved Ornament from Irish Monuments (1926). Poźniej stały się one bezcennym Źródłem informacji na temat rzeźbionych detali w wielu scenach. Jego rekonstrukcje przedstawień i propozycje pierwotnego ich wyglądu przed zwietrzeniem są nadal częściowo użyteczne.

Przy końcu lat dwudziestych (1920) na temat iryjskich krzyży ukazały się pierwsze publikacje Arthura Kingsley Portera (1883-1933), dystyngowanego amerykańskiego historyka sztuki i profesora Harvardu. Od dawna był zainteresowany romańską rzeźbą. Jego Romanesque Sculpture of the Pilgromage Roads zostało opublikowane w r. 1923, a wprowadzenie do Spanish Romanesque Sculpture w r. 1928 zwróciło uwagę historyków na ważność iryjskiej rzeźby dla sztuki europejskiej. Poszukiwania i praca nad wczesnośredniowieczną rzeźbą europejską spowodowały, że przeniósł się do Irlandii. Niestety Kingsley Porter w swojej stymulującej pozycji The Crosses and Culture of Ireland (1930) ograniczył się do opublikowania pięciu wykładów, które wygłosił w Metropolitan Museum of Art w Nowym Jorku. Jego przyjaciel Bernard Berenson w pozycji Aesthetics and History in the Visual Arts wspomniał, że gdyby Porter ukończył swoją pracę, to mógłby udowodnić, że styl iryjskiej rzeźby monumentalnej został przeniesiony do Francji i znalazł swój dalszy rozwój w rzeźbie Chartres i Rheims.

Publikacje Kingsley Portera sprowokowały Françoise Henry (1902-1982) do napisania pierwszego większego artykułu o początkach iryjskiej ikonografii. Była francuskim historykiem i archeologiem, a życie poświęciła pracy nad wczesną iryjską sztuką. Jako uczennica Focillona w Paryżu interesowała się rzeźbą. Jej praca doktorska La Sculpture Irlandaise pendant les douze premiers siècles de l'ère chrétienne opublikowana w r. 1933 jest wielką retrospekcją nad rzeźbionymi krzyżami i kościelną rzeźbą w Irlandii. Chronologię krzyży iryjskich ustaliła już w publikacji z r. 1930, omawiając ikonografię krzyży. We wszystkich następnych pracach ta chronologia nie uległa zmianie. Nie została w sposób zasadniczy zmieniona aż do obecnego czasu. W ostatniej pozycji, w artykule Around an Inscription: The Cross of the Sriptures at Clonmacnois (JRSAI 1980 r.), poddała rewizji datowanie tzw.krzyży biblijnych. $Z$ pomocą rzeźbiarza Domhnalla Ó Murchadha była w stanie efektywnie potwierdzić powszechnie przyjmowany poczattek $\mathrm{X}$ w. jako daty powstania krzyża biblijnego w Clonmacnois. Jej raport dla Cultural Relations Committee of Ireland zatytuowany: Irish High Crosses (opublikowany w roku 1964) jest niejako wprowadzeniem do powyższej publikacji. Pracowała bez wytchnienia dokonując przeglądu całości zagadnienia i dokonując wielu odkryć.

Helen M. Roe (1895-1988) celowała w pracach nad krzyżami iryjskimi prowadzonych w terenie. Jej krótkie przewodniki są bezcenne w podróży. Jej praca $\mathrm{w}$ lokalnych stowarzyszeniach szła równorzędnie $\mathrm{z}$ publikacjami z za- 
kresu ikonografii. Jej osiagniecia zostały uhonorowane w r. 1987 praca zbiorow/a pod redakcją E. Rynne: Figures from the Past. Studies on figurative art in Christian Ireland. Praca ta odzwierciedla ogromne zainteresowanie krzyżami iryjskimi, a od tego czasu ukazano ich wiele aspektów na różnych lokalnych konferencjach i w stowarzyszeniach.

\section{STRUKTURA, PODZIAL I IKONOGRAFIA K R Z Y Ż Y IR Y J S K I C H}

We wczesnym chrześcijaństwie krzyże były znakiem poniżenia i egzekucji aż do czasów Konstantyna Wielkiego, który uchylił prawo skazywania na śmierć przez ukrzyżowanie. Na wczesnych iryjskich krzyżach rzadko pojawiał się relief Chrystusa ukrzyżowanego. Był on stosowany w poźniejszym czasie. W iryjskiej rzeczywistości krzyże nie były wyrazem kary, ale wcielenia Syna Bożego i znakiem Chrystusa jako osoby cierpiącej za ludzkie grzechy. Krzyże pojawiły się na tym obszarze w przeciagu czasowym od w. VII do XII i obecnie jest trudno ustalić jaką pełniły funkcję.

Krzyż iryjski składa się z pionowego, kamiennego trzonu przerwanego w górnej części poprzeczka, bazy i kaptura, stanowiącego rodzaj daszka, nałożonego na górne ramię. Ramiona krzyża połączone są pierścieniem (36 krzyży jest o pustym pierścieniu, wiele pierścieni jest wypełnionych wewnatrz i wiele krzyży nie ma pierścienia). Krzyż czasami przybiera formę piramidalną a baza ma kilka schodków. Rzeźbiony jest ze wszystkich stron. Może być wykonany z kilku kawałków kamienia, ale nie jest to zasadą.

Najstarsze krzyże były rzeźbione na wygładzonej powierzchni wolno stojącego kamienia, w naturalnym jego kształcie. Trzy krzyże w Carndonagh (na północnym zachodzie w kantonie Donegal) wyciosano w kamieniu. W niedaleko położonym Fahan Mura, płyta kamienna wraz z zarysowanym krzyżem, stojąca na cmentarzu przykościelnym, zawiera jedyną w Irlandii wczesną inskrypcję grecką Chwała Ojcu wraz ze sformuowaniem chwała i honor, przyjętym na synodzie w Toledo w r. 633. Krzyż utkany za pomocą szerokich wstażzek przypomina dekorację znajdującą się w Book of Durrow (około roku 650). Oba te elementy dają podstawę do datowania krzyża na połowę wieku VII. Nie ma natomiast pewności odnośnie datowania wielu innych krzyży znajdujących się w tym regionie, chociaż wyrzeźbione na boku wolno stojącej płyty kamiennej w naturalnym jej kształcie lub ukształtowane przez ociosanie bloku kamienia doprowadzając go do kształtu krzyża, wskazują na wczesne powstanie. Były one stawiane przy klasztorach, z których nie pozostało śladu lub tylko nieliczne ruiny. Większa ich ilość została odkryta wzdłuż zachodniego wybrzeża wyspy, gdzie znajdowało się stosowne miejsce dla rekolekcji lub życia pustelniczego. Krzyże rzeźbione lub wyryte na postawionych płytach kamienia maja kształ krzyża greckiego otoczonego kołem, $\mathrm{z}$ ramionami przechodzącymi w spirale, lub krzyża łacińskiego $\mathrm{z}$ zakończeniami w kształcie klinów. Leżące na ziemi grobowe płyty kamienne zachowały się w licznych znanych klasztorach jak na przykład w Clonmacnois. Tutaj wyryty 
krzyż został połączony z inskrypcją. Imiona zawarte w krótkich modlitwach są identyfikowane $\mathrm{z}$ tymi, które znajdują się $\mathrm{w}$ zachowanym Annales $\mathrm{z}$ początku w. VIII. Jednakże krzyże celtyckie, o ile wiadomo, nie są pamiątkami komemoratywnymi, związanymi z miejscem pochówku ${ }^{1}$.

Krzyże celtyckie były stawiane w obrębie klasztorów, dla ochrony przed złem i jako punkty zebrań na ceremonie religijne. Rodzaj wybranych biblijnych tematów, wyrzeźbionych na bokach krzyży, świadczą że spełniały one w niektórych przypadkach określoną funkcję w liturgii Kościoła. Inne krzyże wyznaczały granice posiadłości. Inskrypcje na niektórych krzyżach świadcza, że miały charakter wotywny. Inskrypcja na podstawie południowego krzyża w Kells w kantonie Meath mówi, że jest to „krzyż Patryka i Kolumby” (PATRICII ET COLUMBE CR/UX/). Rysunek w Book of Mulling z w. VIII pokazuje plan klasztoru o założeniu w kształcie koła, wewnątrz i na zewnątrz którego umieszczone są krzyże dedykowane Chrystusowi z dwunastoma apostołami i Duchowi Świętemu, oraz prorokom Starego Testamentu i Ewangelistom. W Iona było wiele krzyży, z których zachowały się poświęcone św. Marcinowi i św. Janowi. Krzyże mają orientację wschód-zachód. ${ }^{2}$

Dzięki badaniom nad inskrypcjami na krzyżach celtyckich chronologia ich jest w zasadzie rozpoznana. Zwykle u podstawy krzyża było pozostawione miejsce na umieszczenie napisu, jakkolwiek na krzyżu opata Muiredach'a (zm. w roku 923) w Monasterboice inskrypcja została dodana później. Krzyż ten pochodzi z początku w. X i należy do tej samej grupy co krzyż wykonany dla króla Flann'a Sinna (lata 879-916), jak głosi inskrypcja (stał on naprzeciw zachodnich drzwi katedry w Clonmacnoise, a obecnie znajduje się w muzeum, powstałym obok ruin katedry). Krzyż w Kinnitty, w kantonie Offaly, był

${ }^{1}$ E. H. L. S ext o n, A Descriptice and Bibliographical List of Irish Figure Sculptures of the Early Christian Period with a Critical Assessment of their Significance, Portland-Maine 1946, s. 4 n.; H. R i c h a r d s o n, J. S c a r r y, An Introduction to Irish High Crosses, Dublin 1990, s. 10 n.; B. M e h a n, The Book of Durrow. A medieval masterpice at Trinity College Dublin, Dublin 1996.

${ }^{2}$ E. H. L. S ex to n, A Descriptice..., s. 182-187; B. B r a n d t - F ö r s t e r, Das Irische Hochkreuz. Ursprung, Entwicklung, Gestalt, Stuttgart 1978, s. 146 n., il. 19; H. R i c h a rds o n, J. S c a r r y, An Introduction..., s. 15. Poezja Oengus'a Culdee, autora Martyrologium w VIII w., świadczy o chroniącej funkcji krzyży, powstałych w miejscach gdzie on żyl:

Disert Bethech where dwelt the man

Whom hosts of angels were wont to visit;

A pious cloister behind a circle of crosses,

Where Oengus son of Uilven used to be.

Tis is Clonenagh he was reared,

In Clonenagh he was buried:

In Clonenagh of many crosses

He first read his psalms.

Inny wiersz jest skierowany do opata w Durrow:

$O$ Cormac, beautiful is thy church,

With its books and learning

A devout city with a hundred crosses..

(F. H e n r y, Irish High Crosses, Dublin 1964, s. 18-20). 
ufundowany przez ojca króla Flann'a - Maelsechnaill mac Maelruanaid, który panował w latach 846-862. Napis głosi: „Modlitwa za Colman'a, który wykonał ten krzyż dla króla Irlandii. Modlitwa za króla Irlandii”, „Modlitwa za króla Maelsechnaill, syna Maelruanaid'a. Modlitwa za króla Irlandii”. Maelsechnaill ogłosił siebie królem Irlandii w roku $859^{3}$.

Krzyże przynależą do kilku wielkich grup stosownie do ich lokacji i stylu. Granice czasowe powstania ustalone są dzięki nielicznym inskrypcjom i porównaniu rzeźb do kompozycji znajdujących się w rękopisach illuminowanych. Ich rozwój można podzielić na cztery etapy. Najwcześniejsze krzyże z pierścieniem przechodzącym przez cztery ramiona wyróżniają się dekoracją abstrakcyjna, ornamentalna, pokrywająca główne pola boków krzyża. Następnie sporadycznie, ale znacząco, jako główne przedstawienia zaczęły pojawiać się sceny biblijne. Mieszanina przedstawień ornamentalnych i figuralnych poprzedza moment $w$ którym zastosowano w większości przedstawienia figuralne. W ostatniej grupie krzyży znajdują się mające pojedynczą figurę, zwykle Chrystusa ukrzyżowanego, lub biskupa, w wypukłym reliefie w części centralnej, w miejscu połączenia ramion krzyża ${ }^{4}$.

Najwcześniejszą grupę, której najlepszym przykładem jest tzw. północny krzyż w Ahenny, stanowią krzyże które pochodzą z okresu od w. VIII do IX i są lokalizowane w kantonach Tipperary i Kilkenny. Krzyże te wykonywane w kamieniu naśladowały drewniane, dekorowane metalowymi blachami. Zarysowane listwy na krawędziach i guzy pośrodku mogły sugerować emaliowane gwoździe czy nity i połączenie płyt metalowych, przylegających do trzonu krzyża. Niekiedy listwy i guzy zdają się wskazywać na elementy mocujące pierścień do ramion krzyża. Gwoździe te nie pełnią jednak żadnej funk-

${ }^{3}$ F. Hen ry, Irish High Crosses, s. 18; H. R i chard son, J. Sc a r ry, An Introduction..., s. 16, 35, 44-45; H. M. R o e, Monasterboice and Its Monuments, second edition, Dundalk 1993, s. $27 \mathrm{n}$.

${ }^{4}$ E. H. L. Sexton, $A$ Descriptice..., s. 39 n.; H. Richards on, J. S carry, $A n$ Introduction..., s. 17; Françoise Henry dzieli krzyże na siedem grup. Do pierwszej grupy przynależą krzyże znajdujące się $w$ kantonach Tipperary i Kilkenny, o dekoracji nawiązującej do snycerskich ozdób metalowych z guzami i o motywach plecionkowych. Są to miejscowości: Ahenny, Kilkieran, Lorrha, Inis Cealtra, Tibberaghny, Killamery, Kilrea i południowy krzyż w Clonmacnois. W drugiej grupie znajdują się krzyże w: Bealin, Banagher (obecnie w Muzeum Narodowym w Dublinie), północny krzyż w Clonmacnois. Trzecią grupe stanowią krzyże wykonane w granicie na zachód od gór Wicklow i w kierunku południowym w dolinie Barrow, w miejscowościach: Old Kilcullen, Moone, Casteldermot, Ullard, Saint Mullins. Różnią się od pozostałych rodzajem materału, w którym zostały wykonane, zgeometryzowaniem rzeźbionych części o prostopadle zakończonych krawędziach i wysokością. W czwartej grupie zostały umieszczone krzyże w Kells, szczególnie krzyż Patryka i Kolumby. Na piątą grupę składają się krzyże w: Armagh, Killary, Arboe, Donaghmore, Downpatrick, Connor i Clones. W szóstej grupie znalazły się krzyże biblijne w: Monasterboice, Clonmacnois i Durrow. W ostatniej, siódmej grupie, mieszczą się krzyże powstałe w oparciu o krzyż z Lukki, z wielką postacią ukrzyżowanego Chrystusa i biskupa z pastorałem. Sa to krzyże w: Dysert O’Dea, Kilfenora, Killaloe, Killeany, na wyspie Aran, Clare, Roscrea, Mona Incha, Cashel, Glendalough i Tuam F. Henry, Irish High Crosses, s. 13 n.). W podobny sposób grupuje krzyże E. H. L. Sexton, A Descriptice..., s. 1-43. 
cji. Krzyże naśladują wyroby $\mathrm{z}$ emalii $\mathrm{i}$ anglosaskie wyroby ze szlachetnych metali, wykładane drogimi kamieniami.

Zmiana w dekorowaniu krzyży nastapiła wraz $\mathrm{z}$ większym zainteresowaniem Biblia, duchową reformą Céli Dé lub Culdee. Dekoracje ornamentalne na krzyżach w Ahenny, Kilkieran, Kilree i Killamery przygotowały drogę dla obrazów figuralnych, umieszczonych w miejscach bardziej centralnych i przeniesienia ornamentów na boki lub miejsca o mniejszej ważności. Dwa krzyże zdają się świadczyć o przemianach w dekoracji i przejściu od ornamentu do wyobrażeń figuralnych: południowy krzyż w Clonmacnois oraz krzyż „Patryka i Kolumby" w Kells. Obydwa mają zwiazzek z Iona. Południowy krzyż w Clonmacnois zawiera duże podobieństwa do ornamentyki na krzyżach grupy Ahenny, ale ma także scenę ukrzyżowania na boku zachodnim. Dekoracyjne, semisferyczne guzy wyróżniają się dzięki wyraźnemu reliefowi i naśladują te znajdujące się na krzyżach w Iona, na przykład na krzyżu św. Marcina, gdzie guzy otoczone są wyobrażeniami wężów. Krzyż „Patryka i Kolumby” w Kells mimo niewielkich rozmiarów jest pełen witalności i piękna. Pochodzi z czasu pierwszego najazdu Wikingów na Iona i exodusu zakonników do Kells, w początku w. IX. Wyjątkowo pośród innych krzyży ma wyrzeźbione symbole czterech Ewangelistów jak to jest widoczne w Book of Kells, gdzie wół, lew, orzeł i człowiek przedstawiane sa ,przy każdej okazji"s.

Duża grupa około trzydziestu krzyży rozrzucona od północy, od kantonu Carlow ku południu, jest pokryta scenami figuralnymi. Nazwane zostały krzyżami biblijnymi, od krzyża ze scenami biblijnymi króla Flanna Sinna w Clonmacnois (crux scriptura), wspomnianego w Annales pod rokiem 1060. Mogą być datowane na okres od w. IX do pierwszej połowy w. X i pokazuja przemiany $w$ irlandzkiej rzeźbie. Po raz pierwszy rzeźbiarze odchodzą od tradycyjnej dekoracji celtyckiej i zwracają się ku opowiadaniu, w przedstawieniach odznaczających się realizmem postaci i faktów. Być może zmianę spowodował najazd Wikingów i konieczność utrwalenia treści i wartości chrześcijańskich w obliczu zagrożenia. Nowy styl wymagał pierwowzorów, których zapewne dostarczyły prace karolińskie, mające na oprawach ksiąg podobne biblijne sceny. Wiele $\mathrm{z}$ nich stanowi powtórzenie przedstawień wczesnochrześcijańskich ze Starego i Nowego Testamentu, jak również z życia eremitów św. Pawła i św. Antoniego, którzy są nazwani ojcami monastycyzmu. Biblijne sceny nawiązują do zbawienia i Eucharystii. Kontynuuja program znajdujący się w malarstwie katakumbowym i rzeźbie sarkofagowej. Podkreślają pomoc Boga w przeciwnościach jak w przypadku Daniela wśród lwów, czy Noego. Do tego dołączone są sceny ze Starego Testamentu, które są prefiguracja Chrystusa i sceny z Nowego Testamentu, a w szczególności cuda. Iryjskie po-

${ }^{5}$ J. A. C a lver t, The Early Development of Irish High Crosses and their Relationship to Scottish Sculpture in the Ninth and Tenth Centuries, Berkeley 1972; H. R i c h a rd s o n, J. S c a r r y, An Introduction..., s. 17-18; The Book of Kells, Described by Sir E. Sullivan, Bart., with additional commentary from an Enquiry into Art of the Illuminated Manuscripts of the Middle Ages by J. A. Bruun, Reprinted, London 1995; B. Me e h a n, The Book of Kells. An Illustrated Introduction to the Manuscript in Trinity College Dublin, Reprinted, London 1997. 
ematy i hymny z w. IX zawierają także te same tematy (hymn Colmana moccu Chluasaig). Najnowsze badania wskazuja, że poszczególne sceny mogły służyć do podkreślenia wydarzeń $w$ roku liturgicznym, a niektóre przedstawienia odnoszą się do postaci historycznych. Nawet pojawiały się interpretacje wskazujące na treści mitologiczne. Niewyjaśnione sceny ukazujące polowanie i jeźdźców na koniach są kontynuacją wcześniejszych wyobrażeń. Wiele przedstawień jest niewyjaśnionych. $\mathrm{W}$ tzw. biblijnych krzyżach, w czołowym miejscu, na skrzyżowaniu ramion, $z$ jednej strony ukazane jest Ukrzyżowanie, a $\mathbf{z}$ drugiej strony Sąd Ostateczny. Przedstawienie Sądu Ostatecznego było jedną z głównych idei najczęściej wyobrażanych w średniowieczu. W Monasterboice na krzyżu Muiredacha rzeźba Sądu Ostatecznego niemal w całości pokrywa wschodni bok krzyża. Św. Michał Archanioł jest tutaj pokazany $\mathrm{z}$ wagą prawie dwa wieki wcześniej niż to później zostało powtórzone na tympanonach kościołów na kontynencie ${ }^{6}$.

Sztuka figuratywna znalazła swój finał w momencie, kiedy w wieku XI i 1. połowie w. XII pojawiły się krzyże o innej kompozycji. Są to: krzyż św. Patryka w Cashel z dwoma podpórkami ramion krzyża, okazały krzyż w Dysert O'Dea i krzyże w kantonie Clare, rzeźbione w lokalnym szarym wapieniu oraz ogromny krzyż $w$ Tuam, ufundowany przez króla Turlough O'Connor (lata 1106-1156). Archaiczne tendencje i ornamenty znów znalazły swoje miejsce w sztuce. Spirale zaczynają zanikać, podczas gdy zwierzęta na przemian ze skandynawskimi cechami i kształtami pojawiają się poprzez kontakt $\mathrm{z}$ Wikingami. Na jednym boku zawsze umieszczony jest krucyfiks o śmiałym reliefie. Rozwój krzyży kończy się wraz z nadejściem Normanów przy końcu w. XII, a średniowieczne krzyże sąjuż inne ${ }^{7}$.

Trudno w pełni odpowiedzieć na pytanie, dlaczego były stawiane krzyże celtyckie, jaka była ich funkcja. Dalsze badania źródeł pisanych być może przyczynią się do pełniejszego ich zrozumienia. Wracając jednak do czasów Konstantyna Wielkiego wiemy, że krzyż był użyty jako znak triumfu, zwycięstwa Chrystusa i chrześcijaństwa. Święto Podniesienia Krzyża Św. stało się ważną uroczystością w Kościele ${ }^{8}$. Chociaż iryjskie krzyże wyróżniają się inno-

${ }^{6}$ E. H. L. Sexto n, A Descriptice..., s. 17 n.; H. Rich ardson, J. Scarry, $A n$ Introduction..., s. 18-19; B. B randt-Förstner, Das Irische Hochkreuz, s. 50 i ns.; R. S t a l l e y, Irish High Crosses, Dublin 1996, 15 n. Na temat związków krzyży iryjskich ze sztuką koptyjską (legenda o życiu świętych Antoniego i Pawła) patrz: A. K. P o rter, An Egyptian Legend in Ireland, „Marburger Jahrbuch für Kunstwissenschaft” 5 (1929), s. 1-14; Na temat związków krzyży iryjskich ze sztuką na kontynencie europejskim patrz: H. M. R o e, Monasterboice, s. 17, 24, 46, 48, 62; taż, The High Crosses of Kells, Reprinted, Dublin 1988, s. 22, $33,37-40,47-49$.

${ }^{7}$ E. H. L. Sext o n, $A$ Descriptice..., s. 31-35; H. R ich ardson, J. Scarry, $A n$ Introduction..., s. 19-20.

${ }^{8} \mathrm{C}$. C e c c h elli, Il Trionfo della croce. La croce e $i$ santi segni prima e dopo Constantino, Roma 1953, passim; R. H. S to r ch, The Trophy and The Cross: Pagan and Christian Symbolism in the Fourth and Fifth Centuries, Byzantion, 40, 1970, s. 99 n.; Y. C h r is te, Vision de Mathieu (Matth. XXIV-XXV). Origines et développement d'une image de la Seconde Parouise, Paris 1973, s.16, 45-46; M.W e r n e r, The Cross-Carpet Page in the Book of Durrow: The Cult of the True Cross, Adamnan, and Iona, „Art Bulletin" 72 (1990), nr 2, s. 175 n. 
ścią w Europie, to jednak mają swoje odpowiedniki w sztuce koptyjskiej, a także we wschodnim chrześcijaństwie, szczególnie w Armenii i Gruzji. $Z$ około r. 500 zachowała się koptyjska tkanina $z$ ornamentem $w$ formie krzyża jaki spotykamy w Irlandii. Ramiona krzyża otoczone są pierścieniem a dolna belka wchodzi za pomocą trzpienia w bazę o jednym uskoku, poszerzoną u podstawy. Tkanina znajduje się w Instytucie Sztuki w Mineapolis'. W Armenii i Gruzji kamienne budowle (pomniki) zwieńczone krzyżami były stawiane między w.V i VII. Spora ich ilość zachowała się. Zwykle mają one kubiczną bazę i prostokątną nastawę (czasem jest to trzon słupa). Boki ich niekiedy podzielone są na segmenty zawierające sceny biblijne, podobnie jak to jest widoczne na krzyżach iryjskich. W Armenii budowle te zanikły wraz z najazdem Arabów. Armeński „kaczkar” (ang. Khatchkar), czy kamienny krzyż, pochodzi $\mathrm{z}$ dziewięciowiecznego krzyża wieńczącego stojący słup. „Kaczkar” jest to płaska płyta kamienna położona pionowo na cokole, z wyrytym na jej czołowej stronie krzyżem. Krzyże stawiał pierwszy apostoł Armenii św.Grzegorz Oświeciciel, a drewaniany Krzyż św.Niny świadczy o nawróceniu Gruzji na chrześcijaństwo w w. IV. Dwa wieki później wybudowano kościół Krzyża świętego w Mtszeda (ang. Mtskheta). Sztuka konstantyńska pozostawiła ślad ${ }^{-} w$ postaci krzyży iryjskich, w zwiazku $z$ tradycją stawiania wolno stojących budowli, upamiętniających wygraną bitwę, co było powszechnym zwyczajem w czasach rzymskich. Wiele przykładów, jak stojące kolumny, zachowało się. Zwykle była to wysoka kolumna lub obelisk stawiany na kubicznym postumencie. Na Kaukazie w rzeczywistości chrześcijańskiej krzyż wieńczył taki monument oznaczając zwycięstwo Chrystusa ${ }^{10}$. Przed bitwą przy moście Milwijskim w roku 312 sam Konstantyn widział krzyż na niebie, jak podaje Euzebiusz z Cezarei, a po zwycięstwie wybudował łuk triumfalny w Rzymie w roku 315.

Zwycięstwo było okazją do wielkiej radości w rzymskiej armii. Po zwycięskiej bitwie generalska flaga była stawiana na zewnątrz namiotu wodza, wraz $\mathrm{z}$ jego tarczą $\mathrm{i}$ wieńcem laurowym. Zwycięski laur lub girlanda przez niektórych autorów jest uważana jako źródło pierścienia na krzyżu iryjskim. W Żywocie Konstantyna jest powiedziane jak cesarz w wyniku swojej wizji rozporządził, aby umieszczono monogram Chi-Rho $w$ wieńcu laurowym na zwieńczeniu państwowego sztandaru. Chi-Rho lub wojskowy krzyż umieszczony wewnątrz koła jest częstym motywem wczesnej sztuki chrześcijańskiej $^{11}$. W sztuce iryjskiej ramiona krzyża niejako przepruwają i przechodzą przez ten pierścień. Stąd nasuwałby się tylko jeden wniosek, że pierścień jest aureolą wokół krzyża, który oznacza Chrystusa. Tymczasem wiele innych supozycji zostało wysuniętych $\mathrm{w}$ związku $\mathrm{z}$ pierścieniem wokół krzyża. Jedna $\mathrm{z}$ nich, zmierzająca ku funkcjonalnemu wythumaczeniu pierścienia mówi, że w drewnianych krzyżach były to proste podpórki ramion krzyża, które poźniej

${ }^{9} \mathrm{R} . \mathrm{S}$ t a 1 l e y, Irish High Crosses, s. 9-10, 12, il .6.

${ }^{10} \mathrm{H}$. R i c h ar d s o n, J. S c a r r y, An Introduction..., s. 21-22.

${ }^{11} \mathrm{~S}$. K o b i el u s, Krzyż Chrystusa. Od znaku i figury do symbolu $i$ metafory, Warszawa 2000 , s. 195 i ns., il. 95. 
w rzeźbie kamiennej ze względów estetycznych zamieniono na półkola. Inna mówi o związkach $\mathrm{z}$ prehistorycznym kultem słońca. W wierszach iryjskich Chrystus jest niekiedy porównywany do słońca ${ }^{12}$. Nie ma wątpliwości, że krzyż z pierścieniem był w użyciu w Irlandii we wczesnym okresie. Jest on wygrawerowany na wielu kamiennych płytach $w$ większości $z$ w. IX. Jedna z nich z r. 720 w Clonmacnois jest zidentyfikowana dzięki Annales. Obecność procesyjnych krzyży $\mathrm{z}$ pierścieniem $\mathrm{w}$ trakcie sprawowania liturgii jest widoczna na bazie północnego krzyża w Ahenny. Tutaj duchowny niesie taki krzyż poprzedzając funebralny pochód ${ }^{13}$. Także w przykładzie $z$ około r. 800 jest mowa o krzyżu z pierścieniem. W Mszale Stowe (Royal Irish Academy) jest mowa o kole jako części krzyża. Pouczenie odnośnie podziału hostii z okazji Bożego Narodzenia i Wielkanocy mówi o dwódziestu częściach uzyskanych z połamania pierścienia krzyża. Użycie pierścienia dla otoczenia ramion krzyża w Irlandii było powszechne. Nie wiadomo jednak, dlaczego wychodzą one poza pierścień, jeżeli umieszczenie go wewnątrz koła było powszechnym motywem w sztuce ${ }^{14}$.

Baza krzyży iryjskich w kształcie schodów, kapturek nałożony na górne ramię krzyża i idea crux gemmata, odnoszą nas do Jerozolimy. W w. IV Konstantyn $\mathrm{z}$ matką-Helena wybudował nad grobem Chrystusa kościół Zmartwychwstania i Grobu. Schody na bazie krzyża iryjskiego nawiązują do wzgórza Trupiej Czaszki. $Z$ relacji pielgrzymów wiemy, że tam był umieszczony krzyż znaleziony przez św.Helenę. Do krzyża prowadziły schody. Nad grobem Chrystusa została wybudowana rotunda, $\mathrm{z}$ rzędem kolumn wewnątrz (Euzebiusz, Życie Konstantyna). Uległa ona zniszczoniu w czasie najazdu Persów na Palestynę w w. VII. Wiemy o niej z relacji pielgrzymów, którzy zwozili do Europy ampułki z wyrytą na nich, między innymi, podobizną grobu Pańskiego. Według relacji pielgrzymów wzniesiony przez Konstantyna kościół miał srebrne drzwi i w nim był przechowany krzyż Chrystusa, ozdobiony złotem i gemmami. Ponad krzyżem widniało otwarte niebo (być może baldachim ozdobiony gwiazdami) ${ }^{15}$. Krzyż ten ozdobiony wyrobami ze złota i wykładany drogimi kamieniami mógł stać się inspiracją dla grupy krzyży iryjskich tzw. Ahenny. Wiadomo, że crux gemmata występuje w mozaikach, chociażby w apsydzie kościoła Św. Punencjany w Rzymie (około r. 400), czy tej z wieku

\footnotetext{
${ }^{12}$ Przykładem może być litania do Matki Boskiej:

$A$ rigdorais rogaidhe triasar chin $i$ cri

Grien taithnemhach togaide, Isu mac De bii

$O$ royal door elect, throught which came into the body

The shining choice Sun, Jesus, Son of the living God.
}

(H. R i ch a rd s o n, J. S c a r r y, An Introduction..., s. 23).

${ }^{13}$ E. H. L. S ext on, $A$ Descriptice..., s. 50; H. R i chardson, J. Sc ar ry, $A n I n-$ troduction, s. 34; R. S t a 11 e y, High Irish Crosses, s. 13, il. 5b.

${ }^{14} \mathrm{H}$. R i c h ard s o n, J. S c a r r y, An Introduction..., s. 24.

${ }^{15}$ D. B a l d i, Enchiridion locorum sanctorum. Documenta s.evangelii loca respicientia, Jerusalem 1982, s. 619 n.; B. F i l a r s k a, Poczatki sztuki chrześcijańskiej, Lublin 1986, s. 198-199, passim; M. W e r n e r, The Cros-Carpet Page..., s. 205. 
VI w apsydzie kościoła Św. Apolinarego in Classe w Rawennie ${ }^{16}$. Adamnan, dziewiąty opat $\bar{w}$ lona (lata 6 79-704) pozostawił opis budynków w Jerozoilmie w dziele De Locis Sanctis. Otrzymał te informacje od bp. Arkulfa, który mieszkał w Jerozolimie przez dziewięć miesięcy. Arkulf narysował plan grobu Chrystusa i wybudowanego nad nim kościoła. Rysunek znalazł się w dziele $D e$ Locis Sanctis, wykonanym około roku 683 dla zakonników w Iona (obecnie w Wiedniu, Rp. 458, fol. 4v). Według niego ze sklepienia zwisał ogromny świecznik w kształcie koła z lampami, a poniżej stał srebrny krzyż, umieszczony w tym samym dole, co drewniany, na którym wisiał Chrystus ${ }^{17}$.

Podobnie jak stopnie na podstawie krzyży iryjskich odpowiadają stopniom prowadzącym do krzyża na Golgocie w Jerozolimie, tak kapturek nałożony na górne ramię krzyża odnosi się do rotundy wybudowanej przez Konstantyna na miejscu grobu, aby zaznaczyć miejsce Zmartwychwstania. Dwa rodzaje tych kapturków można znaleźć na krzyżach iryjskich. Większość przyjmuje kształt małego domku lub zadaszonego kościoła, z kwiatonem, jak to jest widoczne w miniaturze ukazującej świątynię Salomona w przedstawieniu Kuszenia Chrystusa w Book of Kells. Inne występują w znikomej ilości w grupie krzyży w sąsiedztwie Slievenamon i wyglądaja jak pszczeli ul. Kapturek na krzyżach z grupy Ahenny, czy krzyżach figuralnych może przypominać budowlę postawioną nad grobem Chrystusa. Podobne kapturki występują na krzyżach w Gruzji. Ogromne, przyołtarzowe krzyże rzeźbione w drewnie, pokryte metalową dekoracja przetrwały w kościołach Svanetii. Sanktuarium Grobu Pańskiego symbolizuje zwycięstwo nad śmiercią i triumf krzyża. Kapturek na górnych ramionach krzyży oznacza Syjon, Niebiańskie Miasto, Niebiańskie Jeruzalem ${ }^{18}$.

Z tych rozważań wynika, że iryjskie krzyże są częścią chrześcijańskiej tradycji, która szeroko rozprzestrzeniła się w świecie. Irlandia została pozostawiona samej sobie na skraju Europy, podczas gdy kraje sąsiednie zwróciły się ku poganizmowi w wiekach V i VI, po najazdach barbarzyńców. Kościół w Irlandii rozwijał się, a wraz z nim nauka i iluminowanie kodeksów, powstawały nowe budowle. Krzyże iryjskie z wieku IX i X są świadectwem tego wczesnego rozwoju, którego brak na kontynencie Europy. Krzyże te są ważne dla zobrazowania całości procesu rozwojowego sztuki chrześcijańskiej.

${ }^{16}$ C. C e c che 11 i, Il Triomfo della Croce, il. 55, 81; B. F i lar s k a, Poczatki sztuki.., s. 251, il. 258; J. B e ckwith, Early Christian and Byzantine Art, Beccles and London 1979, s. $118-119$, il. 95.

${ }^{17}$ B. F i l a r s k a , Poczq̨tki architektury chrześcijańskiej, Lublin 1983, s. 162 n., il. 265; H. Richardson, J. S c arry, An Introduction..., S. 24-25; M. Werner, The Cross-Carpet Page..., s. 200 i ns., il. 16.

${ }^{18} \mathrm{H}$. R i chards o n, J. S c arry, An Introduction..., s. 25-26; B. M e h a n, The Book of Kells, s. 10, il. 6; tenże, The Book of Durrow, s. 46-47. 


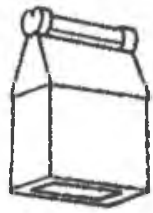

1. Struktura krzyża iryjskiego.
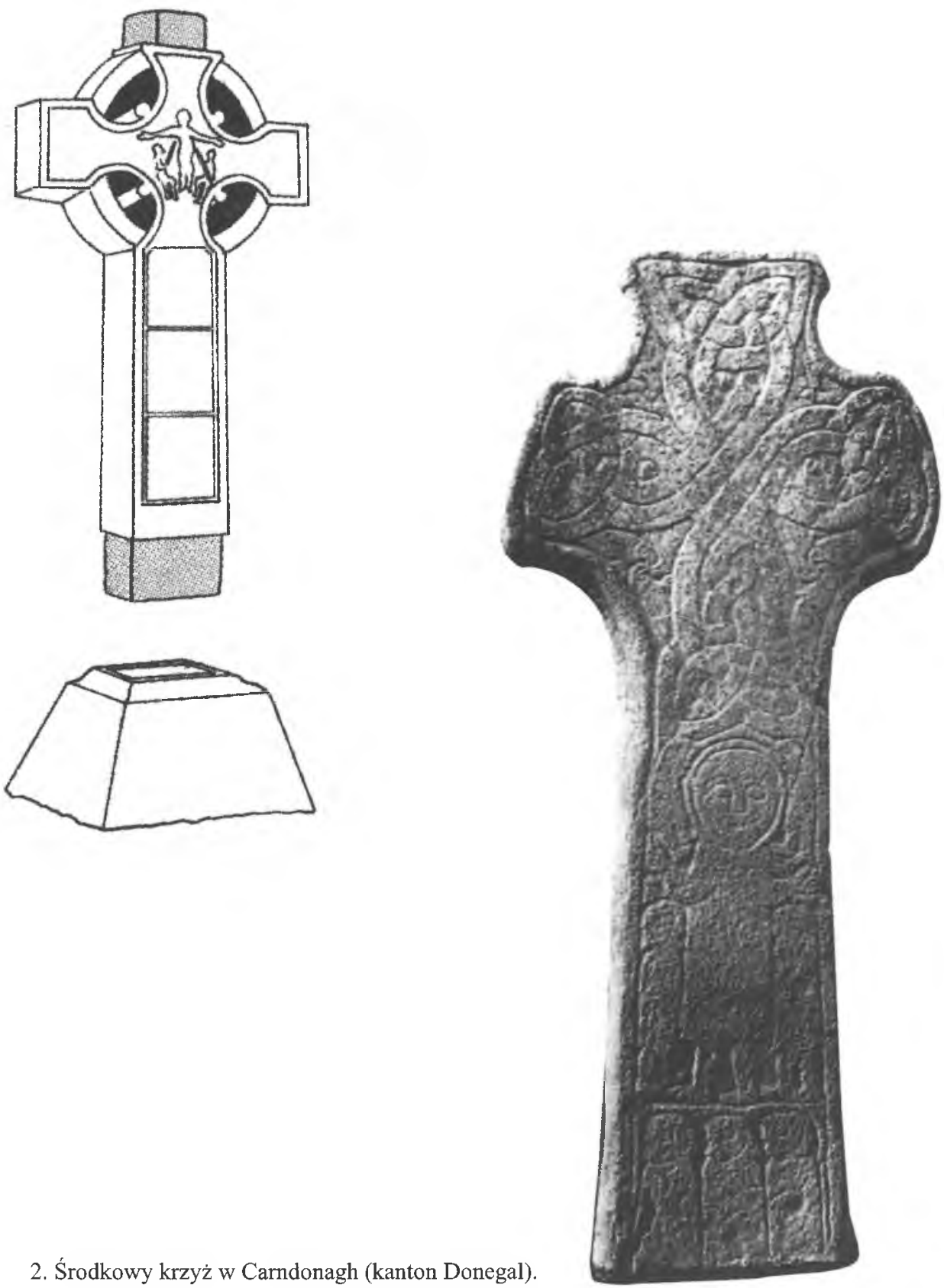

2. Środkowy krzyż w Carndonagh (kanton Donegal). 
S

+ MARK

+ JEREMIAH

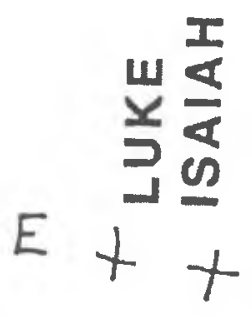

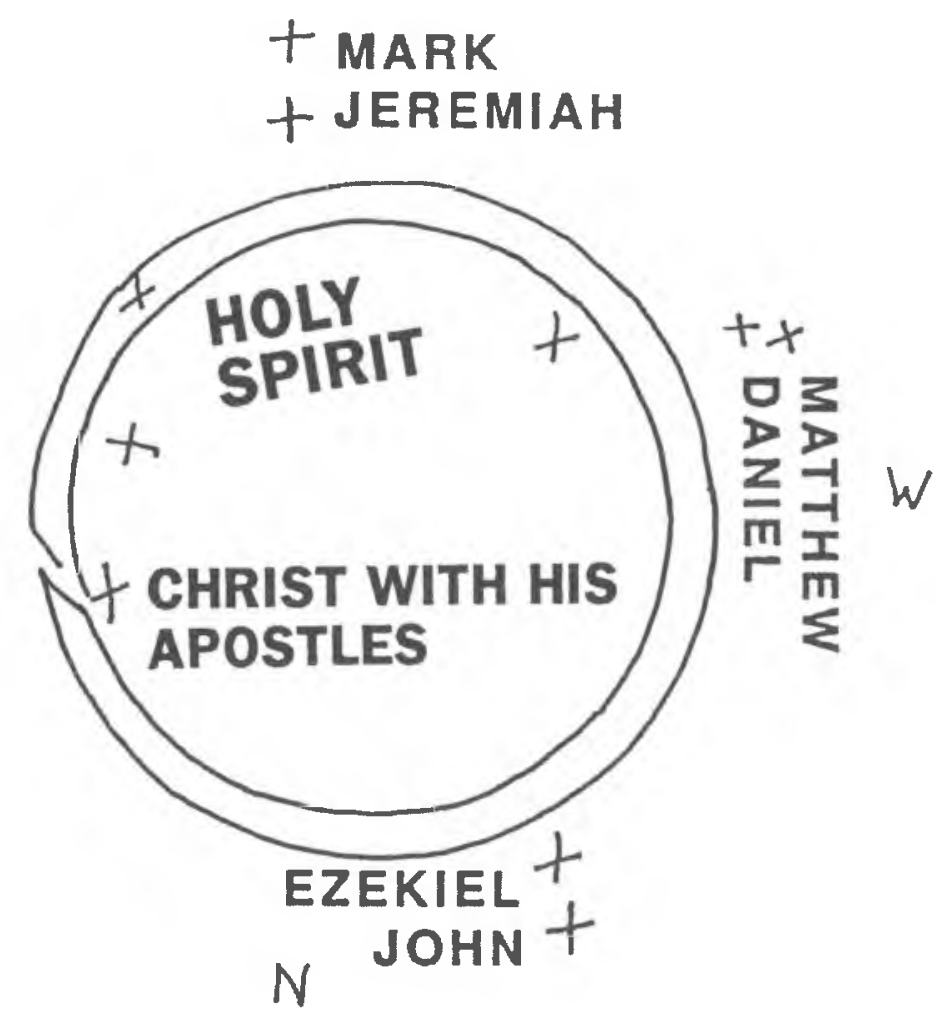

3. Rysunek założenia klasztornego w Book of Mulling. 


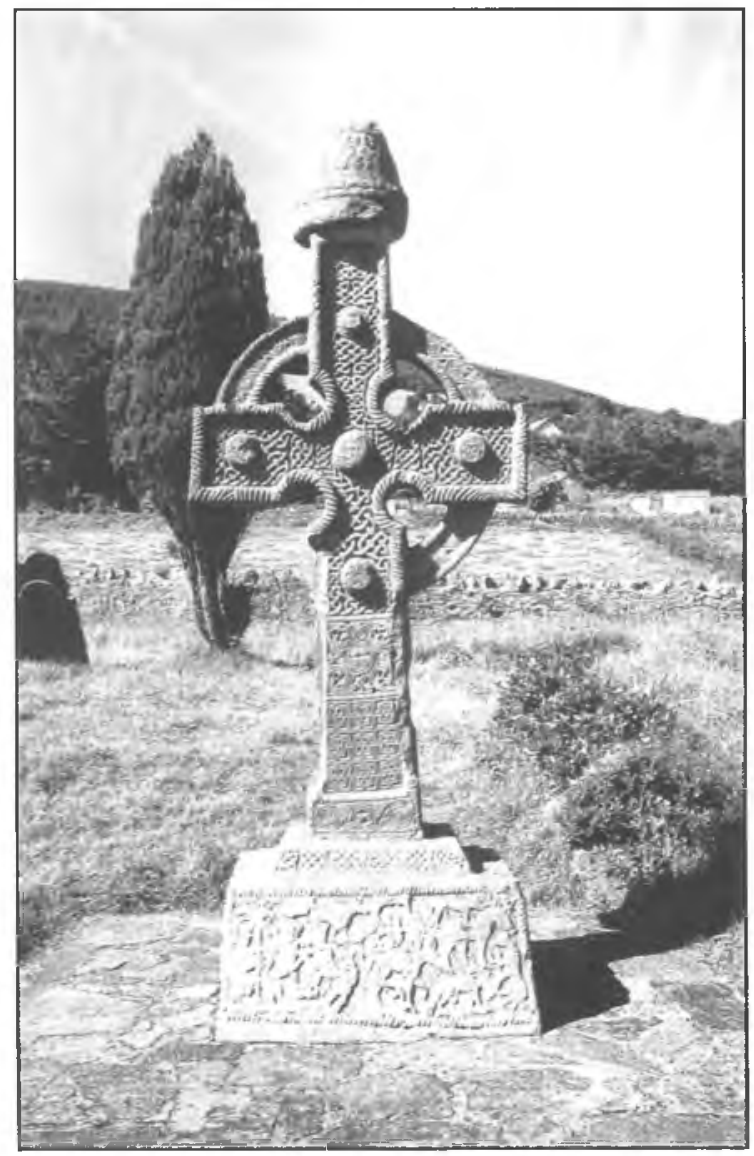

4. Północny krzyż w Ahenny (kanton Tipperary). 


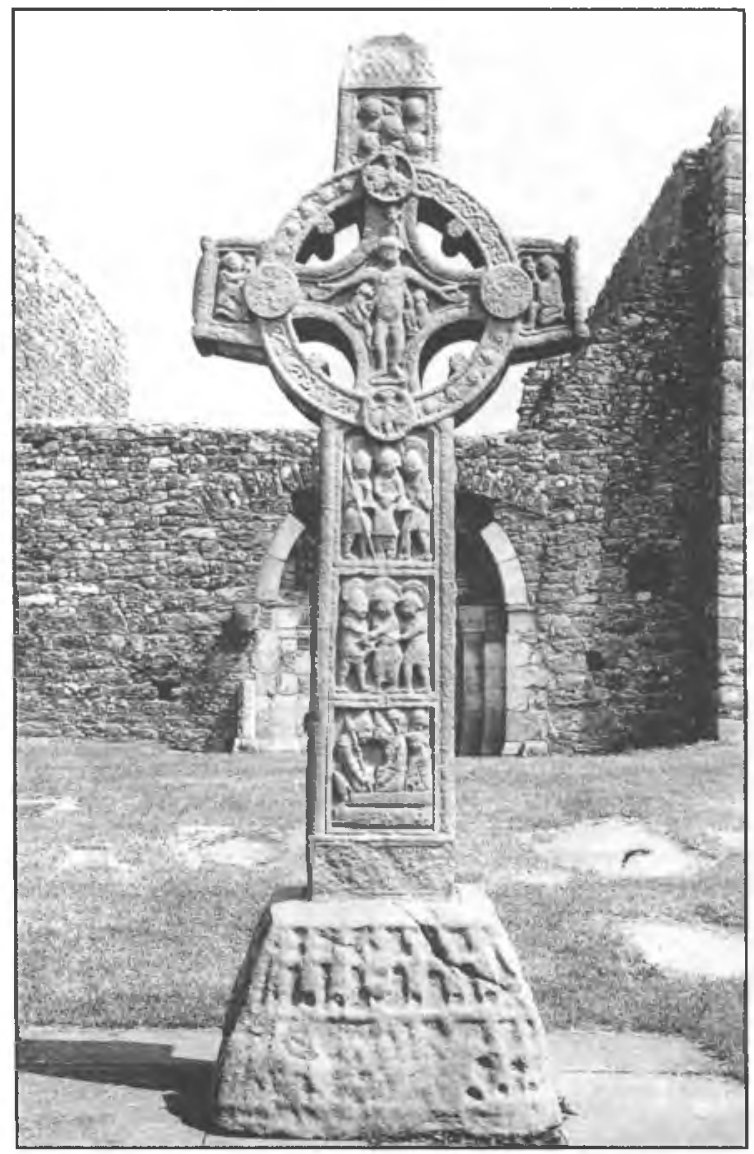

5. Crux scriptura króla Flanna Sinna w Clonmacnois (kanton Offaly). 


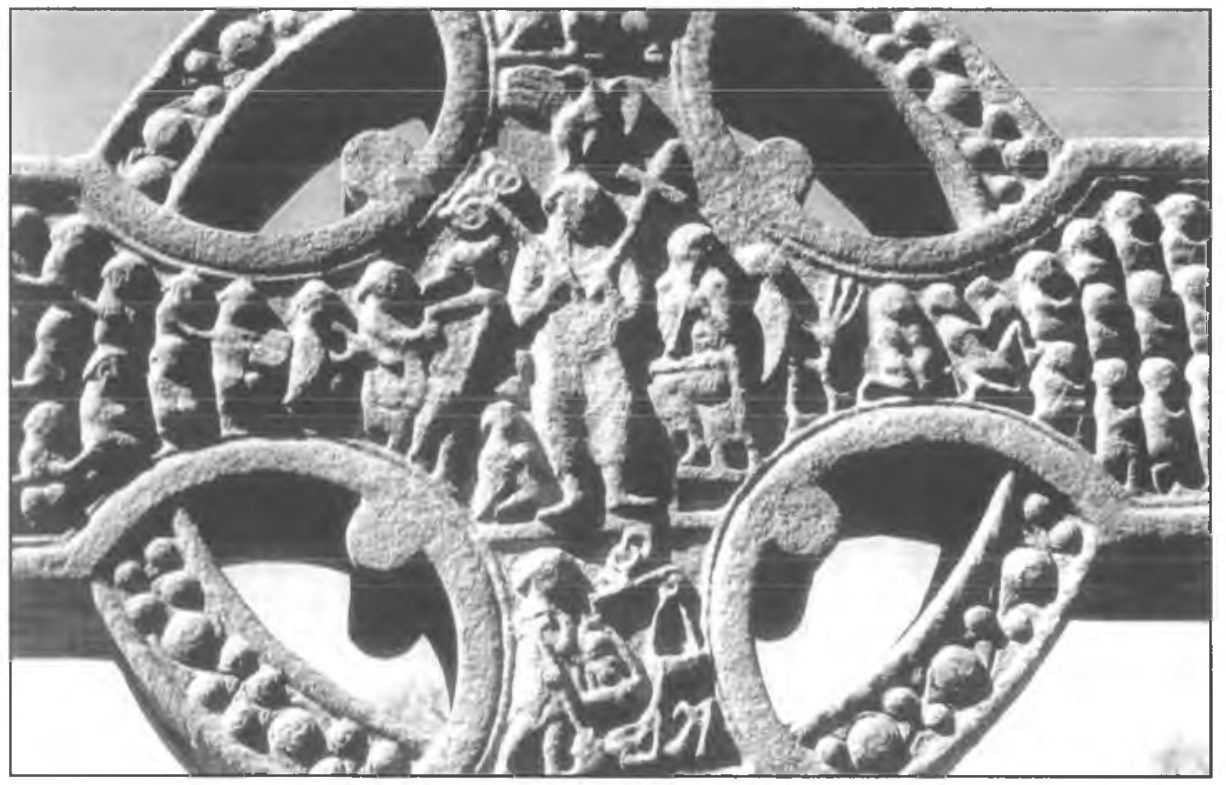

6. Krzyż biblijny opata Mulredacha w Monasterboice (kanton Louth).

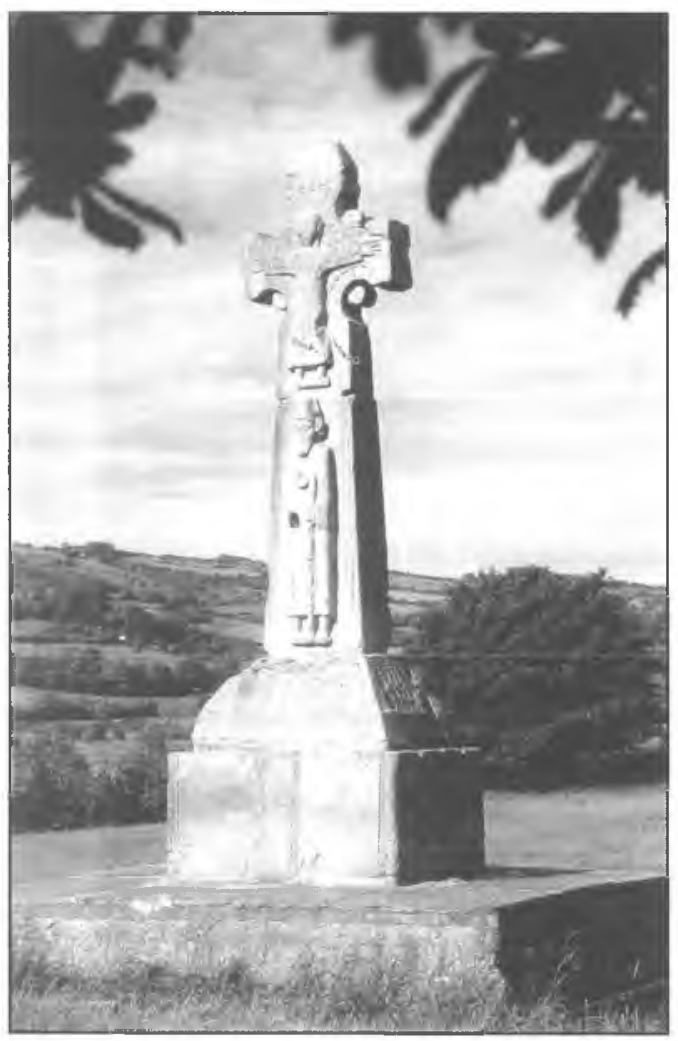

7. Krzyż w Dysert O Dea (kanton Clare). 